\title{
ON WAITING WILLFULLY IN URBAN UGANDA: Toward an Anthropology of Pace
}

\author{
ANNA EISENSTEIN \\ University of Virginia \\ (iD https:/ / orcid.org/0000-0002-6643-4691
}

Olivia knew that once she got married, everyone would expect her to become pregnant as soon as possible. "Of course" she intended to marry and have children, she told me, but she wanted to "stabilize" first: to work a bit, set a plan for starting a business or going back to school, and buy clothing and housewares to establish her personal style. ${ }^{1}$ In the process, she expected to build relationships that would in turn shape her future marriage, family, and lifestyle. As such, Olivia saw waiting to marry as a way of "loving herself."

In this article, I consider how such willful waiting for marriage and motherhood figures in young women's efforts to advance through the life course in Uganda, arguing that their temporal orientation is at odds with the forms of agency often assumed to underlie effective social action. Much previous work on time and agency has emphasized the "stuckness" of global youth, an approach that is grounded in a model of liberal agency that overly privileges speed and selfactualization. In contrast, the women I came to know in urban Uganda deliberately punctuated their movement through the life course with periods of patient waiting. Thus, rather than viewing pauses in progress as an obvious symptom of material lack, I consider how pauses in the life course are both strategically employed and valued as being pregnant with possibility. 
The political scientist Diane Singerman (2007) developed the concept of waithood to describe the expanding period of time between adolescence and full social adulthood that characterizes young adults' lives under neoliberal economic conditions. Soaring youth-unemployment rates and high costs of marriage make it increasingly difficult for young people around the globe to achieve the markers of social adulthood, namely, to marry, establish households, and support their relatives (Durham and Solway 2017). Across ethnographic cases in Africa particularly, the literature documents the shame, tedium, and restlessness that pervades experiences of waithood, especially for young men as they pass their time talking politics in barbershops (Weiss 2009), holding elaborate tea ceremonies (Masquelier 2019), or watching foreign films together (Mains 2011). As such, the prolonged suspension between childhood and adulthood threatens the stability of national governments and economies by tempting youth toward anomie, violence, and sex work (e.g., Hansen 2005; Singerman 2007; Dhillon and Yousef 2009; Jeffrey 2010; Honwana 2012, 2013). By emphasizing the pains and dangers of delayed entries into adulthood, the waithood literature seems to suggest that humans' natural inclination is to move forward through the life course as quickly as possible.

As an alternative to approaches that privilege speed, efficiency, and self-actualization, I offer pace - that is, strategic pausing - as an analytic frame. To consider pace means to look at the various forms of agency and levels of control that different social actors can exercise over their time and movement. Drawing on a rich genealogy in social theory, pace recognizes the fundamentally interpersonal and relational nature of movement. In “Time and Social Structure," Meyer Fortes (1949) described the composition of households and lineage groups as shifting over time based on the members' life stages in relation to one another. Alfred Schütz (1951) developed his theory of social relationships based on the coordination of separate persons' "inner time," as in members of a string quartet communicating through sound and gesture. While concepts of tempo and rhythm emphasize ambient temporal stimuli (Durkheim 1965; Evans-Pritchard 1969; Mauss 1979; You 1994; Guyer 2007; Bourdieu 2008; Bandak 2014; Archambault 2015), and while the concept of entrainment refers to the syncing up of internal bodily rhythms with external temporal cues (Collins 2014; Coe 2015, 2016), pace offers something different in that it draws attention to the situated intentionality involved in linking one's life up with others'.

I came to the idea of pace through the image of two people walking down a path together; to remain side by side, if one speeds up or slows down, so must the other. In line with anthropological work that has dismantled the notion of agency 
as freedom from external pressures (Ahearn 2001a, 2001b; Mahmood 2005; Keane 2007; Laidlaw 2014; Scherz 2014; Khan 2018), studies of gendered temporalities in Africa reflect alternative ideas of agency. For instance, Mende women in rural Gambia utilize contraceptives to time their pregnancies in such a way as to maximize the number of divinely allotted children they will bring forth successfully (Bledsoe 2002); Catholic nuns in Uganda organize their orphanage budgets in light of their faith in divine providence (Scherz 2013); and young women in urban Morocco beautify themselves so as to precipitate the kind of conjugal future they hope God has destined for them (Elliot 2016). Similarly, as urban Ugandan women stop-and-go en route to adulthood, they do so in relation to others to whom they find themselves, or wish themselves to be, connected, especially God.

Although waiting is far from being a passive position (Crapanzano 1986; Kwon 2015; Melly 2017), who waits for whom, for what, and under what conditions are acutely political questions, revealing how different social actors are positioned vis-à-vis hierarchies of power (Bourdieu 2000; Knauft 2002; Dungey and Meinert 2017). As Adeline Masquelier (2019) has recently argued, multiple temporalities and forms of futurity unfold simultaneously, converging, intersecting, and layering atop one another. Like Masquelier (2019, 5), I am interested in the ways that waiting not only signifies "enforced inactivity" but also becomes part of the "daily micropolitics through which forms of being-in-the-world and spaces of belonging are elaborated" against a backdrop of severely narrowed futures due to economic insecurity and widespread joblessness. Building on Masquelier's insights, my ethnography of pace highlights how the timing of movement is contingent and relational at the same time as it is intentional and strategic.

In this article, I draw on twenty-one months of fieldwork in Mbarara, carried out between 2015 and 2018, to show how women living in urban Uganda today experience and negotiate their place in the world by pacing their entry into social adulthood. By focusing on women (when, to date, the majority of studies on youth temporalities have concentrated on men), I join others in demonstrating that waiting, as a temporal form of agency, is informed by particular constructions and realizations of gender and gendered institutions, such as marriage and childbearing (see also Johnson-Hanks 2006; Weiss 2009; Cole 2010; Gilbert 2016; Archambault 2017; Moore 2018; Inhorn and Smith-Hefner 2020). I am not claiming that waiting to advance through the life course was something only women did, but that the reasons for and practices of waiting are distinctly gendered.

In what follows, I argue that Ugandan women wait willfully for the right connections to form before moving forward through the life course. I demonstrate 
that this is because they do not prioritize advancing through the life course as fast as possible, but, instead, advancing in mutualistic connections with others. For the same reason, they also take care not to postpone this life course transition too long. Their waithood can thus only be described by attending to the doubleness of contingency and intentionality. To this end, I begin by describing the ways capitalism and urbanization have contoured problems of interpersonal trust in Uganda, tracing how even the most promising urban relationships are haunted by self-interest and fleetingness, both furnished by the anonymity of the city. The risks of relationships are particularly acute for women as they select spouses and/ or become pregnant, and I show how women use pace as a strategy to manage these risks. In doing so, they draw on a vernacular Christian theory of knowledge and insight into relationships in which pausing to "study" others opens spaces in which trustworthy connections might emerge. In this way, hitting the right pace, between rushing and getting stuck, allows women in Uganda to forge connections that might elevate their socioeconomic position. Along the way, the very ambiguity of relationships imbues pauses with the promise of possibility.

\section{PACE IS AN ANSWER TO PROBLEMS OF TRUST}

In southwestern Uganda, a good life (amagara marungi) is understood to flow from a network of harmonious relationships with kin, friends, and spirits who bring various forms of support and blessing into one's life. Hardships follow when one rushes into an attachment with the wrong person, and conversely, when one gets stuck, failing to advance mutualistic relationships.

The dangers of acceleration and the threat of getting left behind not only reflect familiar narratives of capitalist transformation (Harvey 1989; Rose 1996) but also simultaneously refract local explanatory repertoires and social dynamics (cf. Cole and Durham 2007; Chua 2011). Regional idioms of blockage and flow-the "rivers of life" (Turner 1967) — have organized interrelated social processes of production, exchange, and fertility in East and Central Africa for centuries (Feierman 1985; Taylor 1992; Neema 1994; Vokes 2013). In this emic paradigm, flow is positively valued and irregular movement (whether overflow or blockage) has negative consequences. In contemporary Uganda, the process of composing a social and spiritual network from which good life flows involves grappling with increasingly capitalist conditions. At the confluence of urbanization, growing joblessness, companionate marriage, and vernacular Christian discourses on opportunity and discernment, new problems of trust have emerged. 


\section{Capitalist Urbanization}

A regional city of some 100,000 people, Mbarara is surrounded by agricultural areas and is imagined by its inhabitants first and foremost through its contrast to rural life. Like many urban centers, Mbarara is a place where modern belonging seems to be within close reach. Yet the very aspects of urban relationships that fill them with potential - anonymity, proximity, and plurality — also make them risky.

Economic opportunities in Mbarara often seem to dissolve as quickly as they appear. Although Uganda's national economy was strongly committed to liberalization in the 1980s, since that time, the government has gradually increased its restrictions, rendering scarce the private-sector jobs most people imagine obtaining. Formal and informal employees' paydays are often deferred indefinitely, and during my fieldwork I saw this happen to brickmakers, domestic workers, schoolteachers, bankers, insurance agents, shop attendants, restaurateurs, doctors, and university professors alike - who then had to turn to other ways of "finding money" to meet their needs. In this milieu, young people frequently describe their everyday activities as kugiiya, moving about looking for anything from which to "squeeze [out] money" (cf. Jones 2010). In the process, income-seekers all too often fall into bad deals, working for too little pay or getting scammed outright. Through such experiences, people learn to cautiously evaluate others before moving forward with the wrong business partners.

\section{Marital Decision-Making}

For women in Uganda, economic stability is bound up in relationships with men. The women I discuss here all identified as Banyankole (the dominant ethnic group in this part of Uganda) and as Christian (Catholic, Protestant, and Pentecostal in roughly equal proportions). Like most residents of Mbarara, all twelve of my core research participants were born in rural settings and moved to the city as young adults. Their ages ranged from eighteen to twenty-eight. They occupied various class positions, the wealthiest being a university professor, the poorest, a seller of roadside snacks. Some were married, others were not. Some were mothers, but none were married mothers. Despite age, class, and marital differences, I view these women as inhabiting a powerful common category. What unified their experience was, first, their urban residence, and second, their eligibility for married motherhood. In conceptualizing this position in the life course, I draw on the idea of the "vital conjuncture" developed by Jennifer Johnson-Hanks $(2006,22)$ to refer to "socially structured zones of possibility that emerge around specific periods of 
potential transformation in a life or lives." I understand my informants to have all been inhabiting the vital conjuncture during which they were eligible to become married mothers, but the route for getting there was under negotiation.

In southwestern Uganda, a woman enters social adulthood by marrying into a man's family and bearing children belonging to his clan. Although institutions and rites of passage structure idealized notions of life stages, in practice, as Johnson-Hanks (2006) points out, such passages are only variably achieved, most often through long-term negotiations and social and economic disruptions. This certainly holds true for marriage and motherhood in Uganda. However, whereas the waithood literature has framed waiting almost entirely as compulsion, in contemporary Uganda, navigating potential futures involves decision-making processes in which willful waiting figures as a valuable strategy.

A hundred years ago, aspirational marriage practices in this region were firmly entrenched in a set of evaluative practices in which the two families "investigated" (kucondooza) each other to identify personality traits, social dynamics, diseases, challenges, habits, and values that seemed to run in the family (Murembe 2015). These investigations took the form of secret and open consultations with others who knew the family, indirect inquiries carried out by a go-between, and continuing mutual assessment of the marriage as it unfolded. Specifically, the marriage process consisted of an initial visit from the prospective groom to the bride's father (arranged by a go-between), the payment of bride-price (which would first have to be raised through contributions from the groom's kin and friends), the introduction ceremony, and then the ceremonial giveaway of the bride - all of which took place on separate occasions at the bride's father's home (Roscoe 1923). After the bride had gone to reside at the groom's home, her family would visit her multiple times and gradually release her to contribute productive and reproductive labor within and for her new husband's family, contingent on observing evidence of their care, provision, and goodness toward the wife. Familial projects of precautionary information-gathering were thus central to Kinyankole marriage.

Yet as more and more people - especially young, unmarried people-have moved to Mbarara, aspirational marriage practices have become less embedded in extended kinship relations. Companionate marriage ideals likely began to take hold in this region in the 1950s as colonial labor migration declined, making wife-sharing practices less socially and economically necessary (Doyle 2013). During the 1970s, near-universal primary schooling facilitated a culture of courtship in Mbarara, and Shane Doyle's (2013) review of church records from this era has revealed a marked increase in the number of cases where genitors refused to accept the re- 
sponsibilities of fatherhood outside marriage. It was not until the 1980s, however, that rural-urban migration to Mbarara genuinely picked up, with the municipality's population increasing by 338 percent between 1984 and 2013. With urbanization, the possibilities for families to investigate each other have changed considerably. In Mbarara today, rising rates of cohabitation, diminishing rates of formal marriage, and shifting anxieties around infertility mean that parents and kin are often only brought into the process of betrothal after the fact. En route to marriage, the women I came to know in Mbarara found themselves alienated from rural kin and feeling quite alone as they navigated potentially reproductive relationships.

Urban relationships are creating a fertility complex at the heart of social transitions to adulthood in Uganda: simply put, women want marriage first, but men want children first. Whereas it is advantageous for a woman to be married before beginning to bear children (because she can then feel more certain about the baby's father's committment to supporting her and the child's needs), it is advantageous for a man to have a child or children with a woman before marrying her (because it allows him to ascertain his potential wife's fertility). ${ }^{2}$ This is, of course, a generalization, but the trend is broadly acknowledged. This gendered distribution of risk leads to considerable anxiety and negotiation over couples' marriage-pregnancy sequence, which is compounded by the enduring risk of HIV/ AIDS (Boyd 2015; Parikh 2016).

In navigating the fertility complex pragmatically, women in Mbarara pace their relationships strategically. If they move too quickly, they risk becoming a single mother (an unfavorable position economically and socially) or contracting the disease. If they move too slowly, they risk losing the man. If they hit just the right pace, they stand to achieve an "organized family" (eka y'obuteka). The ideal of an organized family stands out against the backdrop of untrustworthy economic and intimate relationships. An organized family consists of a complementary spousal relationship in which both spouses willingly fulfill their roles in the household, sharing responsibility for their mutual advancement and that of their dependents; in turn, economic success and amagara marungi (good life) accrue. In the transformed landscape of urban life, then, careful pacing is required to create a family that will flourish despite the contemporary threats of fickle and fleeting relationships and economic opportunities.

\section{Christian Temporalities of Opportunity and Discernment}

For many women in Uganda, the often extended, uncertain period of waiting for one's life to come together is a waiting on God. Religion is a central di- 
mension of personal and collective life in Uganda (Scherz 2014; Boyd 2015), and 85 percent of the population is Christian (UBOS 2014). Rather than suggesting that the problems of trust and the importance of pace in Mbarara are Christian phenomena, however, I view Christianity as one way of engaging the gendered problems of trust posed by capitalist urbanization.

Christianity in Mbarara stresses a unique prosperity gospel. Whereas by definition the prosperity gospel says that Christian devotion produces health and wealth, the local variation in Mbarara maintains that a person's exercise of spiritual discernment constitutes the specific mechanism whereby God-given health and wealth come into reach. Resonating with the premarital investigations described above, despite their theological differences, all three of Uganda's most popular denominations (Catholicism, Anglicanism, and Pentecostalism) emphasize the importance of appealing to God for wisdom before proceeding with prospective romantic and business relationships. ${ }^{3}$ In Mbarara today, the Runyankole proverb, "The person who wants to marry should inquire first" (owashwera abuuza), warns against hasty decision-making in any regard, not just marriage. "Observing" or "studying" (kwetegyereza) others facilitates understanding their underlying intentions and any ties they might have to potentially dangerous spiritual others. But it is easy to miss or misinterpret the signs. Seeking God's involvement allows Him to become the "eyes behind your eyes" and to "speak to your inner ears," lending omniscient guidance. When a person effectively consults and obeys God, they can expect to reap material blessings; when a person does not, they may move at the wrong pace and miss out on blessings or incur curses.

In seeking God's insight, waiting is a "modality of attention" (Reinhardt 2018) essential to Christian subjectivity and success. But in contrast to a longing for the Rapture (Robbins 2004) or a resignation to God's plan (Gaibazzi 2012), the waiting I describe here is about attaining this-worldly returns through actively partnering with God. Writing about the Pentecostal prosperity gospel in Zambia, Naomi Haynes (2017) identifies "moving” as a central value to which people aspire: that is, "a recognizable, usually visible, positive change in circumstances," including educational advancement, progress through the life course, and economic achievement realized in observable markers of financial improvement like cars and houses (Haynes 2017, 12). My interlocutors in Uganda aspired toward moving in the same sense. Building on Haynes's observations, I would point out that moving occurs along multiple planes - moving forward through the life course and upward socioeconomically - that must be calibrated. All of this becomes mediated through 
relationships with others, and because untrustworthy others are so prevalent in Mbarara, discernment proves essential. Moving thus requires waiting.

\section{DON'T RUSH}

When Mariam married Gerald, she did not know what she was in for. He had lied to her about his financial situation, telling her that he was much better off than he was. And she had fallen for it. She saw that he drove a car, but she did not notice the oil leaking from it because he could not afford to fix it. She appreciated his fancy apartment but failed to realize why people so often came there looking for him: to collect debts. His clothes were always neat and clean, but Mariam never read the gateman's rudeness as a sign that Gerald had not paid him for washing his clothes in months. Signs of wealth and moral character are easily faked, especially to the untrained eye not used to "looking at money." Shortly after they got married, Gerald was caught accepting bribes at work and lost his contract. He passed the subsequent months watching television and expected Mariam to both earn the money and do all household labor. Despite his irresponsibility, he knew she would find it hard to leave him since he had already put a Christian wedding band on her finger. If she divorced him before having a child, everyone would wonder if she were infertile and it would become difficult to remarry. If she divorced him after having a child, she would be hard-pressed to find a spouse as a single mother. Mariam had been conned.

The figure of the conman (omuyayi) haunts romantic relationships, business deals, and religious encounters alike. He may wear fancy clothes, drive a car, and attend church regularly. But those clothes may be borrowed, the car may have been purchased at the expense of sending his children to school, and even "children of the devil" can be found inside Christian spaces. Embodying the dangers of relationships with strangers, the conman represents the vulnerability in knowing, trusting, and connecting with those unknown to you.

Taking one's time offers protection against such risks. Throughout my fieldwork the refrain topapa, meaning “don't rush," reverberated throughout everyday conversations, church sermons, and family meetings in Mbarara. Although borrowed from Luganda, in Mbarara (where the main language is Runyankole) the word topapa is widely referred to as Kiswahili. The majority of Swahili speakers in southwestern Uganda are Congolese immigrants and refugees, whom Ugandans often cast as untrustworthy others whose desire to live the high life leads them to theft, witchcraft, and crime. While topapa does not in fact stem from the Swahili 
language, the word is "Swahili" in the sense that it reminds hearers of dangerous others whose hidden behaviors may harm.

The logic of topapa applied to a wide range of hazards of urban modernity facing both men and women. When moving by boda-boda (motorcycle taxi), a passenger might gently remind the driver, "Mporampora, mporampora" (Slowly, slowly, slowly, slowly), if he is going too fast. This phrase marks the beginning of the best-known Kinyankole proverb, "Slowly, slowly, the earthworm reaches the well" (Mporampora, ekahisya omunyongororwa aha iziba), which has many other variations beginning with "Mporampora . . . ." One should also avoid choosing a boda-boda too quickly, especially when the driver is unfamiliar or he or his motorcycle do not look clean and well kept: he might be doing drugs, fail to see thieves on the way, or intend to rob or rape you. The temptation to get into an overstuffed taxi (matatu) — although it may bring a person more quickly to their destination or be cheaper since the conductor has accepted so many passengers - should equally be avoided since it dangerously weighs down the vehicle and speaks to the profit-driven motives of the driver-conductor team.

When someone is schooling, elders encourage them to pace themselves through the long journey. If the student tries to push through without taking the time necessary to study for exams, this thinking goes, they will not earn high marks. Although the journey is long, one should not wish to jump a class (skip a grade), because in doing so the student will fail to learn the deeper lessons and forego strong relationships with peers.

The logic of topapa also helps explain the plethora of half-built construction projects that overwhelm Uganda's landscape. Constructing too quickly, my interlocutors explained to me, does not give the materials time to harden and settle into each other; if the builder rushes, his house will fall. ${ }^{4}$ Moreover, spending too much too quickly on one's own project will leave a person financially unable to contribute to others' needs, and their resentment will crumble the home this house was meant to become.

Starting a business also requires patience. If an entrepreneur invests too much at the beginning, before the business has become sustainable, they may "spoil [their] investments, [their] name, and [their] heart," as one young business owner told me. You may have brought people something great, but if they were not ready for it, it will fail. One needs to start slowly so that others come along to help build the business a person has been dreaming of. Moving forward with one's ideas before consulting others will lead to failure and leave others saying, "But he didn't ask [us for our input].” 


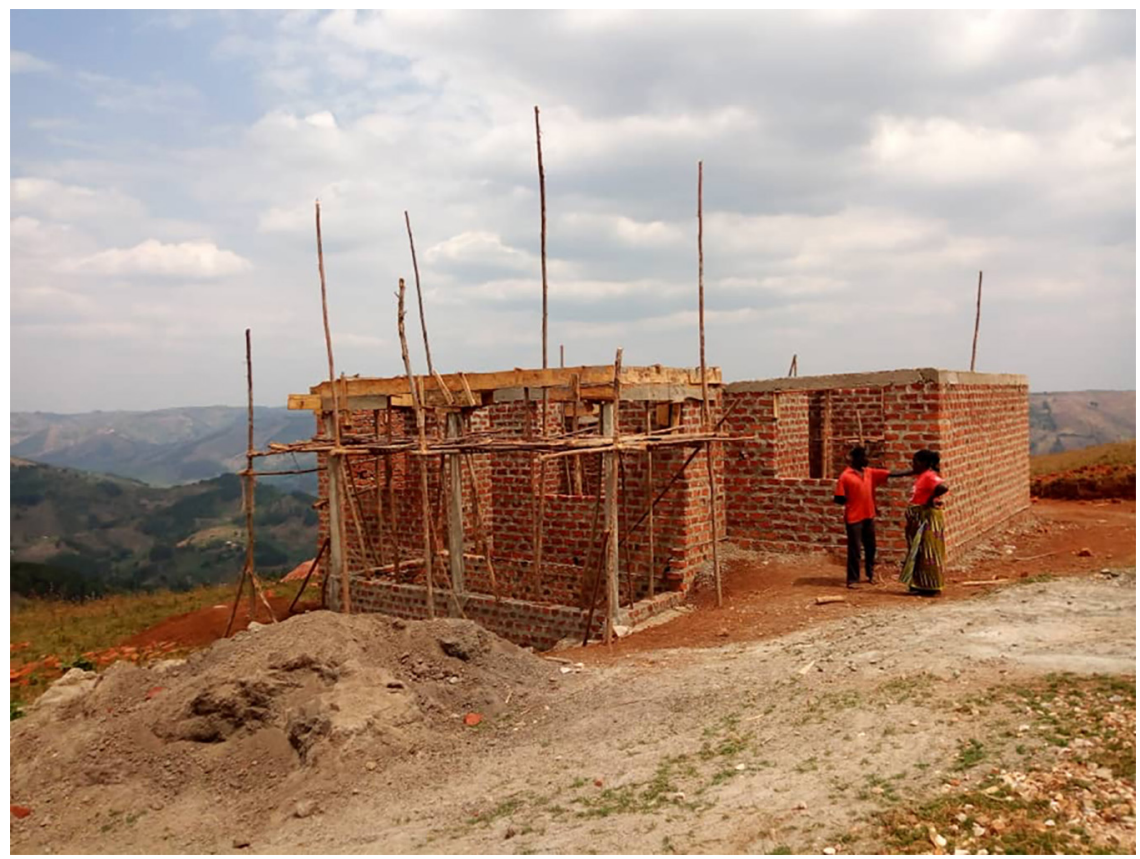

Figure 1. A small, half-built, brick house on the outskirts of Mbarara. This modest construction project was already two years in the making when this photo was taken. Photo by Twesigye Pius.

Sex is another activity that should not be rushed. By moving too quickly during sex, the partners fail to "synchronize," and when one loses out on enjoyment, both partners lose the opportunity that sex offers to "bring some connection” by teaching them to "work together," as an older couple explained to me.

In interpersonal relationships generally, to rush another person to do something you want them to do before they see it for themselves and willingly choose to do it means disregarding their autonomy. Bonds emerging from such pressure are understood as weak and particularly vulnerable to breaking. In the context of growing inequality in Uganda, two persons once moving side by side may find themselves rather suddenly in different positions across social space: under such circumstances, only a strong, "genuine" bond born of mutual free choice can endure.

Through the echoes of topapa, it becomes clear that rushing carries risk on two levels: establishing harmful connections or alienating helpful ones. Against the backdrop of possible unseen dangers, rushing might cause someone to fall into a bad situation instead of reaching their destination, as in the case of falling for a conman, or getting into a traffic accident. On a second level, rushing threatens to alienate others, as evident in the examples of failing to cement relationships 
with schoolmates, focusing one's resources too closely on one's own construction project, allowing others to see and support one's business's growth, and having unsynchronized sex. The dual dangers of moving with bad others or without good others - and the willful waiting that constitutes the wisest alternative to rushing - emerge in the case of Abigail.

\section{Waiting on God}

When Abigail got pregnant, she had been a university student and an active member of the Anglican Church. She had approached a church leader with questions about scripture, and he had proposed they discuss them at her home. But while he was there, before she even really knew what was happening, he impregnated her. ${ }^{5}$ When Abigail later let him know she was carrying his child, he insisted she get an abortion. But Abigail resisted his demands. As her pregnancy unfolded, it reorganized her relationships drastically. She could not complete her courses at school and lost the respect of her church community. The baby's father refused to take financial responsibility for his son. Abigail's parents and siblings likewise said they could not help support the child. (In fact, they felt so much shame toward her that they barely spoke to her for years following the pregnancy.) Only her sister Miranda showed mercy: soon after the baby was born, Miranda allowed them to move into her single rented room with her.

While living with her sister, Abigail befriended one of the neighbors, also a single mother. The two of them decided to chip in together for a phone that could support WhatsApp, an app that provides the most popular mode of textbased communication in Uganda. Whenever it was her turn with the phone, Abigail would chat with men whom she had met through church, school, or friends of friends. Many of them figured as potential marriage partners or financial providers, and WhatsApping with them regularly opened the possibility of advancing these relationships.

Month after month went by, and one after another potential WhatsApp boyfriend fell through. Discouraged, Abigail told me, "Every time I think I may move, something happens. I find doors which look open, I knock, I find they're locked. And really, I don't know why." The reasons why a man might not want to marry Abigail were not insignificant: she already had a son from another man and the boy had no source of support. She also refused to have sex again before being formally married. Although Abigail acknowledged these factors, she held that they should not be insurmountable because she had God on her side. 
Shortly after we celebrated her baby's first birthday, conversations with a wealthy banker began to look promising and he offered to give her a business. Which business would she like to engage in, he asked her. Excited and hopeful, Abigail needed a few days to muster the courage to tell him she wanted to become a tailor. He replied by telling her that dream was not big enough and sent her back to think of a career of which he could be proud. Abigail was taken aback. His response made her feel embarrassed about class differences, but more so, it made her wonder what was behind his offer. She was wary of getting into a situation that appeared to be the answer to her prayers but might in fact tie her to obligations sexual or spiritual — that she did not want. She needed God's discernment to perceive whether or not this man "had an attachment" to which she would become beholden by accepting his gift.

As she often did, Abigail entered a period of prayer and fasting. This consisted of several days during which Abigail would not eat or talk on the phone during the daytime in the interest of focusing on God. On the last day of her fast, she told me she could not pretend she had received an answer from God. She was still "confused" as to whether this man had a good heart or if he was an enemy with evil "connections." Yet I could hear her smiling over the phone as she told me the prayers and fasting had not been in vain, for she had developed "the spirit of listening." She told me, "I'm learning to wait for God's word in me before I proceed. God help [sic] me understand His voice and I follow.” Abigail's time was not to be rushed.

Eventually, the banker got tired of waiting. After upping the ante to include marriage, he warned Abigail that his offer would soon expire. Abigail's sister was about to get married and without any means of paying rent herself, Abigail did not know where she and her baby would go. I sympathized with her that it must be especially hard to wait for God's answer when the man seemed to be offering everything she wanted. But she replied by referring to a verse in Deuteronomy, telling me, and maybe herself, “The things we don't know, we don't waste time [on], because God has not revealed them to us yet. They belong to Him. He has not yet given them to us." She told the man that she could not understand why he was rushing, for God had not yet spoken. She decided to keep waiting, and he went his way. Abigail did not count this as a loss. Crucially, the movement she desired was movement with God.

The examples I have considered thus far have shown the worthwhile nature of patience versus a rush out of waithood. Willful waiting seeks to create a network. Incorporating desirable others (like God) and avoiding undesirable others 
(like conmen) into one's life takes time. It takes time for their true identities and intentions to become evident, and for their wills to align with one's own. These examples have also illustrated that the risks of rushing into marriage and childbearing prove greater for women. Divorced women without children find their fertility called into question; single mothers are significantly less marriageable since they often come with the obligation to feed mouths belonging to another man's clan. Yet even as they cannot afford to rush, women must also take care not to take too long.

\section{DON'T GET STUCK}

In a setting where marriage and children are so highly valued, women who do not bear children, especially within the context of marriage, are considered failures. A woman who does not get married is said to have "fallen in the cooking stones" (kugwa amahega). In a traditional Kinyankole homestead (including some rural households today), women cook over a special set of cooking stones given by the mother-in-law to a new wife shortly after she has married into their family. The wife uses those cooking stones to feed her marriage, and in time, her children. Her daughters soon join her in performing cooking duties, and it is over their mother's cooking stones that they too learn to make fire and prepare food for the time when they will have their own families. If a daughter "falls in the cooking stones," she has fallen into the work of her mother's household and not gotten up. She remains stuck behind the house (the kitchen is always a separate structure behind the house), laboring there and never moving outside of the compound, and thus, hidden from any potential suitors' view. As a Kinyankole proverb says, "What remains inside the homestead beautifies the back of the house" (Ebiguma omu nda bishemeza amarembo). Out of view and connection with others, her labor never graduates to feed her own family as it should, so she remains subservient to her mother and father, working for something that is "theirs" and never her own.

Instead of falling in the cooking stones as such, women today might just as easily fall into their books or their office if they prioritize education or careers at the expense of a timely marriage. Hidden behind the cover of a book or within the walls of an office, their beauty cannot be recognized by those to whom it might matter.

Age thirty is a hard "deadline" by which everyone — men and women alikeshould be married, although the rule is less mutable for women. Urban men refer to women who look "old" but are not yet married as "off-layers" (like hens) who have passed their reproductive prime. As a person approaches twenty-seven, their 
marital prospects become the topic of anxious discussion during family meetings, and sometimes the family investigates possible underlying spiritual causes for the delay. Spiritual forces may block a person from moving, such as witchcraft thrown by an adversary that has "pinned" the unmarried one to some out-of-the-way location and its associated relationships, or spirit spouses who have "locked up" someone in a marriage in the spirit world so that they cannot marry someone on earth. Although most urban women do not live near their kin, all those I knew in their late twenties described the intense family pressure they felt to somehow become "unstuck." One twenty-eight-year-old woman who worked as a research assistant at the university and lived with her widowed mother told me that her mother made her dress up and walk around town every single day so that men would see her and she would waste no more time and attract a husband.

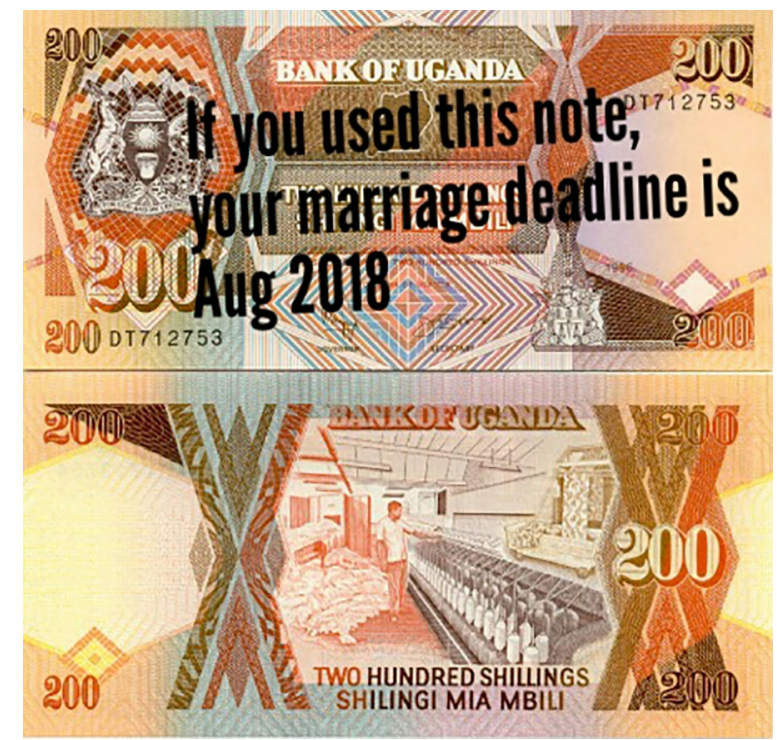

Figure 2. This image depicting the front and back of a two-hundred-shilling note-with text superimposed over the top that reads, "If you used this note, your marriage deadline is Aug 2018”-circulated widely on Whatsapp in July 2018.

The money pictured was used in Uganda until 1996.

At stake in hitting the marriage "deadline" is the socioeconomic status of the family network in which one will become involved. While it is advantageous to marry up, spending too much time chasing a relationship with someone who is "not the same [as you]" (of a similar class position) carries a greater risk of not materializing into marriage. As time proceeds, the pool of eligible bachelors decreases and a woman's prospects for socioeconomic mobility diminish accordingly. 
In the effort to tie oneself to a man, becoming pregnant with his child is sometimes a woman's best strategy. This became clear to me when, just two weeks into a new relationship, Angela, a single mother of two young children, decided to have the injectable contraceptive removed from her arm in the hope that she would soon conceive. As many women do, Angela had faced a false start on the way to social adulthood when her previous marriage had failed; she now wanted to pick up her pace. Leaving her two young children in the care of her mother and never mentioning them to her boyfriend, Angela planned to become pregnant and thereby elicit her new boyfriend's love, and all that might follow from it. Angela imagined this pending pregnancy as a way to move forward in the course to becoming a married mother. Through this, she hoped, those to whom she was already attached (her children and her parents) would also move "up a level" to a more stable financial situation. Although I lost touch with Angela shortly after she stopped contraception, in my fieldwork I encountered several examples of success with just this tactic.

Beginning to have children relatively early in one's life, "while you still have energy," is considered socioeconomically advantageous in another way too. As a twenty-nine-year-old man explained, "I need to get a child so that it inspires me to work hard. If you get children and work money when you are young, life becomes sweet when you are old." Children and the love they evoke thus motivate parents to achieve higher socioeconomic heights. But the stakes of doing so fall along gendered lines. As one twenty-eight-year-old woman told me, "if you at least start [having children] when you are young, then when you have finished, you can get out of the house and do other things"; she herself intended to go to law school. Another mother of young children told me somewhat desperately, "I need to finish with the times of pregnancy. I finished schooling nine years ago. For nine years I have been with no job. Nine years." Both this mother and the prospective lawyer wanted to complete the season of life in which they were pregnant on and off again so that they could move on to employment. The temporal sequence of this shift from reproductive to productive economic activity is a movement toward, or further into, adulthood. Whereas bearing children is obligatory for women, earning money is optional. Those who "finish" with pregnancies earlier have more time to build their careers and connections outside the home, and many women experience "getting out of the house" as personally fulfilling and empowering.

Timing the arrival of children relatively early in one's life is also likely to coincide with the childbearing years of other success-oriented young couples. By keeping up with others who are also marrying and having children, working hard, 
and poised for success, one's friendships with them are more likely to grow. In turn, those friendships can serve as a source of socioeconomic, social, and emotional support, as well as inspiration to keep one's priorities in order. Ultimately, couples who marry and begin having children while they are "still young" are able to benefit from the temporal flexibility and social connections that can propel them to the next socioeconomic level.

Not getting stuck plumbs with the will to wait in that it is not merely postponement of married motherhood that women want, but rather, the proper pacing that will allow them to move out of the house and associate themselves with progress through productive activities and social relations.

\section{PREGNANT PAUSES}

In the tension between not rushing and not getting stuck, pausing emerges as a powerful social technology for creating connections and developing trust in them. Johnson-Hanks (2006, 23) writes that vital conjunctures can be understood "through their horizons, the borders of possibility, desirability, and potential danger, as perceived by the participants." If vital conjunctures are structured by alternative points on the horizon, then relationships are the paths toward or away from those horizon points, and "pregnant pauses" are the means of assessing and solidifying those relationships. Pregnant pauses take many forms, but they always entail coming together with others. As such, they offer opportunities for social actors to "tune in" (Schütz 1951) to each other, furnishing deeper mutual insight and connection. Although pregnant pauses does not constitute an emic phrase, my use of it derives from numerous Kinyankole proverbs conveying that one cannot predict the personality of one's baby before it is born; you simply have to wait and see. ${ }^{6}$ In the same way, comings-together with others are open-ended, their effects underdetermined (cf. Geissler and Prince 2010). Further, as biological pregnancy is a period during which a new relationship gestates within, reorganizing the relationships surrounding it, so too, more metaphorical pregnant pauses prove generative and transformative. The pregnant part of these pauses also hearkens to the gendered identities and subjectivities in relation to which women specifically pace their relationships.

Prayer, elaborate greeting exchanges (in person, online, and over the phone), social visits, and weddings all serve as examples of pregnant pauses. Prayer makes for an especially important pregnant pause. When a supplicant pauses to commune with God, she cannot predict what she might see, hear, or receive, but availing herself of God's perspective allows Him to lead the way. Considering this as crucial 
for punctuating their successful movement through life, hundreds and hundreds of people living in Mbarara attend church in the early morning every day. This is in addition to personal prayer time one might take anytime throughout the day or night. Attendance at special healing and deliverance services at church and periods of private prayer and fasting constitute even more intensive attempts to pause and connect with God. Prayer in turn shapes one's engagements in other pregnant pauses through God-given discernment or other forms of divine intervention.

In-person greeting exchanges provide a moment to stop and look at each other. Regular conversations on WhatsApp — which figure as an everyday priority for almost all the young adults I have come to know in Uganda — serve as a way of keeping up relationships. Phone calls demonstrate care and connection. I was repeatedly amazed at how many phone calls everyone (myself included) received for no apparent reason other than to "check on" the person and make sure they were well. Such calls were often quite short; airtime is charged by the minute in Uganda, and many callers seem expertly to wind down the call and hang up at exactly fifty-nine seconds. Visiting offers another occasion when persons pause to come together in a shared experience, and what might emerge remains openended. To this point, many Banyankole hold that you cannot know if you will spend the night at someone else's house until after you arrive and eat and see how the visit is going. In all these kinds of interactions, a contingent space opens up where, as Abigail often said of her WhatsApp conversations, "you never know" what might happen next.

I caught a glimpse of the importance of this tuning in with others - composing a "we” (Schütz 1951) or a "with” (Goffman 1967) — when my longtime friend, Rachel, wed her husband in church. Although her husband had given her father the full bride-price and completed the traditional marriage ceremonies fourteen years earlier, and by this point they had three children together, Rachel told me that she saw the wedding as a "major spiritual breakthrough." They should have wed long ago, she acknowledged, noting that having failed to attach their family to God for this long had been holding them back: "We don't always move as we should," she said, referring at once to her difficulty getting a job despite having a postsecondary degree, her frequent marital conflicts, and the fact that building their house had taken them longer than desired. With this wedding, they would connect their union to God, which she expected would catalyze further progress in their family's life. At the same time, this story speaks to the role of costly, Western-style "white weddings" in enacting a couple's belonging in a global middle class (cf. Pauli 2011; Solway 2016; van Dijk 2017). By instantiating their connection to God and 
other upwardly mobile families, their church wedding constituted one of many pregnant pauses, or relational technologies of pace, that helped bring others into their movement in and through life.

\section{CONCLUSION}

As a strategy, pace in this ethnographic context is employed to build networks of trustworthy others with whom one might move forward through the life course and upward socioeconomically. Capitalist urbanization produces new forms of precarity for middle-class and aspiring middle-class women, as even Friedrich Engels (2009 [1845]) realized. But whereas modern life is widely experienced as a speeding up under conditions of industrial capitalism, I have shown how, in Uganda, it is the slowing down of social connections that guards against the particular, gendered dilemmas that arise in relation to capitalism and urban life. Gradual, punctuated processes of coming to see, to know, and to trust others over time offer protection against the threats of conmen and of alienation.

This contrast reveals a capitalism in which aspirations for economic success are as much about praying hard as about working hard. ${ }^{7}$ Women in Uganda have confidence in their waiting to develop discernment because they feel that it allows them to be led by God. Their pace thus points beyond a neoliberal formulation of individual accountability for speedy success. Rather, in pausing to seek and submit themselves to divine guidance, women in Uganda simultaneously exercise agency in one sense and sacrifice it in another; agency here is not independence or autonomy, but more like willfulness. They are not waiting for circumstances to change so much as they are waiting on others. In this way their strategic pausing reflects the heightened importance of social and divine connections and coordination for achieving personal progress, modern belonging, and well-being in a world that is always threatening to exclude those who cannot keep up. Not rushing and not getting stuck. Intentionality and contingency.

Considering the reasons women in Uganda have to slow down the progression of time and move forward only at specific moments has shown that these women do not experience waithood as the direct and unavoidable result of the forces of capital restraining them from realizing adulthood at an unfettered pace. Instead, by pausing to come together with others and see what comes forth, they sometimes delay the milestones of marriage and motherhood quite intentionally. In so doing, they engage waithood as a mode of addressing and potentially even transforming their relationships and economic circumstances. In this way, waithood may in fact help generate the conditions of possibility for interactions and 
networks to emerge that might lead to new, different, and possibly better material conditions. This finding indicates that the risks of entering social adulthood at the wrong moment, embedded in the wrong relationships, prove at least as significant as the risks of remaining in waithood.

Understanding the life course as a project to be strategically, contingently negotiated not only has theoretical significance but also applied stakes. International development projects of population control in Uganda have specifically targeted how women spend their time as a site of intervention, seeking to train young women away from "idling" (understood to lead to sex and pregnancy, early and often) and instead convert them into productive economic subjects (Moore 2018). Contradicting the assumption that lack of household or entrepreneurial labor leads to boredom which leads to sex, I have detailed how women in Mbarara deliberately chose to invest in pregnant pauses — which looked like chatting on the phone, texting, hanging out, praying, and going to church - in the express interest of improving their economic opportunities.

Willfully postponing married motherhood is counterbalanced by and aligned with efforts to finish bearing children as early as possible so as to be freed to move on to further education and employment. National government- and international NGO-sponsored girl-child campaigns in Uganda (and elsewhere) advocate "schooling first," reflecting the notion, familiar from Western settings, that childbearing puts an end to educational and career advancement. Yet I have explained how at least some women in Mbarara successfully practice "children first," completing their obligatory pregnancies before moving deeper into educational and career activities during middle age. Because young women in Uganda are so closely identified with their potential maternity, any attempt to empower them must take into account the changing relationship between marriage, fertility, and "getting out of the house" (cf. Paxson 2004). Bearing a child before marrying and/or finishing school may come with risks, but it may also be just the thing that leads to marriage to a good, upwardly mobile man. Further, timing childbearing, marriage, and education around the same time as other success-oriented couples-thus opening the possibility of becoming enmeshed in a powerful network of mutual obligation with them - may prove more important for women's well-being and success than sequencing education before childbearing.

This article has demonstrated how the analytic of pace directs attention to the relational risks, expectations, and desires facing differently positioned persons as they move through life with others. Women in Uganda face more risk than men at this vital conjuncture, so in this context, pace constitutes a particularly 
gendered form of temporal agency. Although it might be tempting to romanticize the pregnant pause, that is far from my recommendation here. Despite the way urban independence and companionate marriage have typically been associated with emancipation in all its positive valences, the women I knew in Mbarara did not find their position an easy one to inhabit. Pregnant pauses offered a tool for reckoning with some of the challenges they faced. Yet pacing placed the burden of orchestrating life projects on women, especially, whose futures and whose children's futures seemed to hang in the balance of moving or failing to move at just the right moment.

\begin{abstract}
Women in Uganda strategically time their entry into married motherhood in relation to others with whom they want to be connected. Although much of the burgeoning literature on "waithood" laments global youth's delayed entry into social adulthood, I show that women in urban Uganda intentionally pause, slowing down their movement through the life course to cultivate networks of interdependence that will propel them not only forward through the life course but also upward socioeconomically. The logics and practices by which they pace themselves point beyond a neoliberal conception of time and agency, instead highlighting the heightened importance of divine connections and social coordination under increasingly capitalist and urban conditions. The lens of pace helps bring into view the situated, multilayered, relational projects of moving through life with others. [Africa; agency; temporality; gender; Christianity; urbanization; life course]
\end{abstract}

\title{
EKIHANDIIKO OMUBUGUFU
}

Abakazi omuri Uganda nibetebekanisiza gye obwiire bw'okutaaha omubushweere n'obuzaire waaba n'ogyeragyeranisa naabo abubarikweenda kwegaita/kuba nabo. N'obu ebihaandiiko ebirikweyongyera kukanya ebirikukwaata aha bunyeeto biraabe nibyooreka okutoonzya ahabw'eminyeeto kukyerererwa kukura, ninyoreka ngu abakazi omumyaanya ekurakureine omuri Uganda nibariindaho bakigyendereire, bakyeendeeza ahamigyendere omumituurire yaabo kwenda ngu babaase kwombeka emikago y'okuhweerahweerana etarikubayaamba kwongyera kubutuura emituurire yaabo kwonka kureka na n'okwongyera kubatunguura omubyentaatsya. Enteekateeka hamwe n'emitwaarize eyibarikutwaazamu n'ehingura ahanyetegyereza y'obweire hamwe n'obugabe bw'okwehitsyaho ebyetaago eya abakurakureine, beitu byongyera kumurika ekyetaago kihaango ky'okumanya ebyenyikiriza hamwe n'okutuuragye n'abaantu omumbeera z'obushuubuzi hamwe n'entunguuka ebiriyo nibikanya. Ekitangaazo ky'emitwarize nikiyaamba kureeba omubury'obuhikire, entebekanisa zitarikushushwana z'okubaasa kutuuragye nabaandi. [Afirika; okweshariramu; ekitari kyobutweire; abikiriza omuri kuristo; ebyomundembo; orugyendo rwamagara] 


\section{NOTES}

Acknowledgments Grateful recognition goes to my research participants in Mbarara. I thank Ira Bashkow, Ida Hoequist, Arsalan Khan, Michelle Morgenstern, Joel Robbins, and China Scherz for intellectual support. I also thank Cultural Anthropology's editorial collective, especially Heather Paxson, and the anonymous reviewers for their helpful feedback. The work was supported by the National Science Foundation, the Philanthropic Educational Organization (PEO), and the University of Virginia's African Urbanisms Humanities Lab, Center for Global Health, and Center for Global Inquiry and Innovation.

1. My interlocutors in Mbarara spoke both Runyankole and English. Where I quote translations of the words they originally spoke in Runyankole, I include the Runyankole in the text or within parentheses.

2. Men worry that women may have previously had an abortion that compromises their subsequent fertility and thus might lock them into a childless marriage. Abortion complications can indeed endanger women's fertility, although figures vary dramatically and suffer from a high response bias, since abortion is illegal in Uganda. Prior to Christianity, infertility was an acceptable reason for divorce, but not so today for couples who have wed in church.

3. See Liz Ravalde (2019) on the increasing similarities across denominations since the growth of Pentecostal and Charismatic movements in the country since the 1980s.

4. Building a house is the one gender-specific activity on this list; it is something every man must do in Uganda, though not necessarily before getting married, especially not in the urban setting. The man will, however, need to pay the rent if he has a wife.

5. I do not call this rape because Abigail herself never did.

6. For instance, "Ebirungi tibyezaara, encwera ezaara ekiryambeba" (Good things don't give birth to things like themselves, a python gives birth to a [harmless rat-eating snake]). The significance of this proverb was explained to me as, "Although the parents are good, they may produce a wild child." Also, "Enda ezaara mwiru na muhima" (The stomach produces an agriculturalist and a pastoralist). The significance of this proverb was explained to me as, "Both agriculturalists and pastoralists come from the stomach, so when you are pregnant you don't know what kind of person you will produce."

7. I thank Heather Paxson for this insight.

\section{REFERENCES}

Ahearn, Laura M.

2001a Invitations to Love: Literacy, Love Letters, and Social Change in Nepal. Ann Arbor: University of Michigan Press.

2001b "Language and Agency." Annual Review of Anthropology 30, no. 1: 109-37. https:// doi.org/10.1146/annurev.anthro.30.1.109.

Archambault, Julie Soleil

2015 "Rhythms of Uncertainty and the Pleasures of Anticipation." In Ethnographies of Uncertainty in Africa, edited by Elizabeth Cooper and David Pratten, 129-48. London: Palgrave Macmillan.

2017 Mobile Secrets: Youth, Intimacy, and the Politics of Pretense in Mozambique. Chicago:

Bandak, Andreas University of Chicago Press.

2014 "Of Refrains and Rhythms in Contemporary Damascus: Urban Space and Christian-Muslim Coexistence.” Current Anthropology 55, no. S10: S248-61.

Bledsoe, Caroline H. https://doi.org/10.1086/678409.

2002 Contingent Lives: Fertility, Time, and Aging in West Africa. Chicago: University of Chicago Press. 
Bourdieu, Pierre

2000 Pascalian Meditations. Translated by Richard Nice. Stanford, Calif.: Stanford University Press. Originally published in 1997.

2008 Outline of a Theory of Practice. Translated by Richard Nice. Cambridge: Cambridge University Press. Originally published in 1972.

Boyd, Lydia

2015 Preaching Prevention: Born-Again Christianity and the Moral Politics of AIDS in Uganda. Athens: Ohio University Press.

Chua, Jocelyn Lim

2011 "Making Time for the Children: Self-Temporalization and the Cultivation of the Antisuicidal Subject in South India." Cultural Anthropology 26, no. 1: 112-37.

Coe, Cati https://doi.org/10.1111/j.1548-1360.2010.01082.x.

2015 "The Temporality of Care: Gender, Migration, and the Entrainment of LifeCourses." Anthropological Perspectives on Care: Work, Kinship, and the Life-Course, edited by Erdmute Alber and Heike Drotbohm, 181-205. New York: Palgrave Macmillan.

2016 "Orchestrating Care in Time: Ghanaian Migrant Women, Family, and Reciprocity." American Anthropologist 118, no. 1: 37-48. https://doi.org/10.1111/aman.12446.

Cole, Jennifer

2010 Sex and Salvation: Imagining the Future in Madagascar. Chicago: University of Chicago Press.

Cole, Jennifer, and Deborah Durham

2007 "Introduction: Age, Regeneration, and the Intimate Politics of Globalization." In Generations and Globalization: Youth, Age, and Family in the New World Economy, edited by Jennifer Cole and Deborah Durham, 1-28. Bloomington: Indiana

Collins, Randall University Press.

2014 Interaction Ritual Chains. Princeton, N.J.: Princeton University Press. Crapanzano, Vincent

1986 Waiting: The Whites of South Africa. New York: Random House.

Dhillon, Navtej, and Tarik Yousef, eds.

2009 Generation in Waiting: The Unfulfilled Promise of Young People in the Middle East. Washington, D.C.: Brookings Institution Press.

Doyle, Shane

2013 Before HIV: Sexuality, Fertility and Mortality in East Africa, 1900-1980. Oxford: Oxford University Press.

Dungey, Claire Elisabeth, and Lotte Meinert

2017 "Learning to Wait: Schooling and the Instability of Adulthood for Young Men in Uganda." In Elusive Adulthoods: The Anthropology of New Maturities, edited by Deborah Durham and Jacqueline Solway, 83-104. Bloomington: Indiana University Press.

Durham, Deborah, and Jacqueline Solway, eds.

2017 Elusive Adulthoods: The Anthropology of New Maturities. Bloomington: Indiana

Durkheim, Émile University Press.

1965 The Elementary Forms of the Religious Life. New York: Free Press. Originally published in 1912.

Elliot, Alice

2016 "The Makeup of Destiny: Predestination and the Labor of Hope in a Moroccan Emigrant Town.” American Ethnologist 43, no. 3: 488-99. https://doi.org/10.1111/ amet.12341.

Engels, Friedrich

2009 The Condition of the Working Class in England. Edited by David McLellan. London: Oxford University Press. Originally published in 1845. 
Evans-Pritchard, E. E.

Feierman, Steven

1969 The Nuer: A Description of the Modes of Livelihood and Political Institutions of a Nilotic People. Oxford: Oxford University Press.

1985 "Struggles for Control: The Social Roots of Health and Healing in Modern Africa." African Studies Review 28, no. 2/3: 73-147. https://doi.org/10.2307/524604.

Fortes, Meyer

1949 "Time and Social Structure: An Ashanti Case Study." In Social Structure: Studies Presented to A. R. Radcliffe-Brown, edited by Meyer Fortes, 54-84. Oxford: Oxford Gaibazzi, Paolo University Press.

2012 “'God's time is the best': Religious Imagination and the Wait for Emigration in The Gambia." In The Global Horizon: Expectations of Migration in Africa and the Middle East, edited by Knut Graw and Joska Samuli Schielke, 121-35. Lueven: Lueven University Press.

Geissler, Paul Wenzel, and Ruth Jane Prince

2010 The Land Is Dying: Contingency, Creativity and Conflict in Western Kenya. New York: Berghahn Books.

Gilbert, Juliet

2016 “'They're my contacts, not my friends': Reconfiguring Affect and Aspirations through Mobile Communication in Nigeria." Ethnos 83, no. 2: 237-54. https://doi.

Goffman, Erving org/10.1080/00141844.2015.1120762.

1967 Interaction Ritual: Essays on Face-to-Face Behavior. New York: Doubleday.

Guyer, Jane I.

2007 "Prophecy and the Near Future: Thoughts on Macroeconomic, Evangelical, and Punctuated Time." American Ethnologist 34, no. 3: 409-21. https://doi. org/10.1525/ae.2007.34.3.409.

Hansen, Karen Tranberg

2005 "Getting Stuck in the Compound: Some Odds against Social Adulthood in Lusaka, Zambia." Africa Today 51, no. 4: 3-16. https://www.jstor.org/stable/4187684.

Harvey, David.

1989 The Condition of Postmodernity: An Enquiry into the Origins of Cultural Change. Malden, Mass.: Blackwell.

Haynes, Naomi

2017 Moving by the Spirit: Pentecostal Social Life on the Zambian Copperbelt. Berkeley: University of California Press.

Honwana, Alcinda

2012 The Time of Youth: Work, Social Change, and Politics in Africa. Sterline, Va.: Kumarian.

2013 "Changing Patterns of Intimacy among Young People in Africa." In African Dynamics in a Multipolar World, edited by Ulf Engel and Manuel Joao Ramos, 2950. London: Brill.

Inhorn, Marcia C., and Nancy J. Smith-Hefner

2020 Waithood: Gender, Education, and Global Delays in Marriage and Childbearing. New York: Berghahn Books.

Jeffrey, Craig

2010 Timepass: Youth, Class, and the Politics of Waiting in India. Stanford, Calif.: Stanford University Press.

Johnson-Hanks, Jennifer

2006 Uncertain Honor: Modern Motherhood in an African Crisis. Chicago: University of Chicago Press.

Jones, Jeremy L.

2010 “Nothing is straight in Zimbabwe': The Rise of the Kukiya-kiya Economy 20002008.” Journal of Southern African Studies 36, no. 2: 285-99. https://doi.org/10.108 0/03057070.2010.485784. 
Keane, Webb

2007 Christian Moderns: Freedom and Fetish in the Mission Encounter. Berkeley: University of California Press.

Khan, Arsalan

2018 "Pious Masculinity, Ethical Reflexivity, and Moral Order in an Islamic Piety Movement in Pakistan.” Anthropological Quarterly 91, no. 1: 53-77. https://doi.

Knauft, Bruce M. org/10.1353/anq.2018.0002.

2002 Exchanging the Past: A Rainforest World of Before and After. Chicago: University of

Kwon, June Hee Chicago Press.

2015 "The Work of Waiting: Love and Money in Korean Chinese Transnational Migration." Cultural Anthropology 30, no. 3: 477-500. https://doi.org/10.14506/ ca30.3.06.

Laidlaw, James

2014 The Subject of Virtue: An Anthropology of Ethics and Freedom. Cambridge: Cambridge University Press.

Mahmood, Saba

2005 Politics of Piety: The Islamic Revival and the Feminist Subject. Princeton, N.J.: Princeton University Press.

Mains, Daniel

2011 Hope Is Cut: Youth, Unemployment, and the Future in Urban Ethiopia. Philadelphia: Temple University Press.

Masquelier, Adeline

2019 Fada: Boredom and Belonging in Niger. Chicago: University of Chicago Press. Mauss, Marcel

1979 Seasonal Variations of the Eskimo. Translated by James J. Fox. London: Routledge. Originally published in 1950.

Melly, Caroline

2017 Bottleneck: Moving, Building, and Belonging in an African City. Chicago: University of Chicago Press.

Moore, Erin V.

2018 "Idle Women, Bored Sex, and the Temporal Interventions of Population Control." Voices 13, no. 1: 74-87. https://doi.org/10.1111/voic.12006.

Murembe, Clemntia Neema

2015 "Women's Protection and Mechanisms of Conflict Resolution in Ankore Families." In Women's Leadership in Peace Building: Conflict, Community and Care, edited by Mirjam van Reisen, 17-32. Trenton, N.J.: Africa World Press.

Neema, Stella

1994 "Mothers and Midwives: Maternity Care Options in Ankole, Southwestern Parikh, Shanti Uganda.” PhD diss., University of Copenhagen.

2016 Regulating Romance: Youth Love Letters, Moral Anxiety, and Intervention in Uganda's Time of AIDS. Nashville, Tenn.: Vanderbilt University Press.

Pauli, Julia

2011 "Celebrating Distinctions: Common and Conspicuous Weddings in Rural Namibia.” Ethnology 50, no. 2: 153-67. http://ethnology.pitt.edu/ojs/index.php/

Paxson, Heather Ethnology/article/viewArticle/6097.

2004 Making Modern Mothers: Ethics and Family Planning in Urban Greece. Berkeley: University of California Press.

Ravalde, Liz

2019 "Deceiving the Spirit: Engaging with the Holy Spirit in Catholic Uganda." Africa 89, no. 1: 147-64. muse.jhu.edu/article/721510. 
Reinhardt, Bruno

2018 "Waiting for God in Ghana: The Chronotopes of a Prayer Mountain." In Ethnographies of Waiting: Doubt, Hope and Uncertainty, edited by Manpreet K. Janeja Robbins, Joel and Andreas Bandak, 113-37. New York: Bloomsbury.

2004 Becoming Sinners: Christianity and Moral Torment in a Papua New Guinea Society. Berkeley: University of California Press.

Roscoe, John

1923 The Banyankole: The Second Part of the Report of the Mackie Ethnological Expedition to Central Africa. Cambridge: Cambridge University Press.

Rose, Nikolas

1996 Inventing Our Selves: Psychology, Power, and Personhood. Cambridge: Cambridge

Scherz, China University Press.

2013 "Let Us Make God Our Banker: Ethics, Temporality, and Agency in a Ugandan Charity Home.” American Ethnologist 40, no. 4: 624-36. https://doi.org/10.1111/ amet.12043.

2014 Having People, Having Heart: Charity, Sustainable Development, and Problems of Schütz, Alfred Dependence in Central Uganda. Chicago: University of Chicago Press.

1951 "Making Music Together: A Study in Social Relationship." Social Research 18, no. 1: 76-97. https://www.jstor.org/stable/40969255.

Singerman, Diane

2007 "The Economic Imperatives of Marriage: Emerging Practices and Identities among Youth in the Middle East.” Working paper 6. Dubai: Wolfensohn Centre for Development/Dubai School of Development.

Solway, Jacqueline

2016 “'Slow Marriage,' 'Fast Bogadi': Change and Continuity in Marriage in Botswana." Anthropology Southern Africa 39, no. 4: 309-22. https://doi.org/10.1080/23323256. 2016.1235980.

Taylor, Christopher C.

1992 Milk, Honey and Money: Changing Concepts in Rwandan Healing. Washington, D.C.: Smithsonian Institution Press.

Turner, Victor

1967 The Forest of Symbols: Aspects of Ndembu Ritual. Ithaca, N.Y.: Cornell University Press.

UBOS (Uganda Bureau of Statistics)

2014 National Population and Housing Census 2014. Kampala: UBOS.

van Dijk, Rijk

2017 "The Tent versus Lobola: Marriage, Monetary Intimacies and the New Face of Responsibility in Botswana.” Anthropology Southern Africa 40, no. 1: 29-41. https:// doi.org/10.1080/23323256.2016.1243450.

Vokes, Richard

2013 "New Guinean Models in the East African Highlands." Social Analysis 57, no. 3: 95-113. https://doi.org/10.3167/sa.2013.570306.

Weiss, Brad

2009 Street Dreams and Hip Hop Barbershops: Global Fantasy in Urban Tanzania. Bloomington: Indiana University Press.

You, Haili

1994 "Defining Rhythm: Aspects of an Anthropology of Rhythm." Culture, Medicine and Psychiatry 18, no. 3: 361-84. https://doi.org/10.1007/BF01379231. 